\title{
Bill Phillips
}

Peter Baker and Deborah Shaller (eds.), Detecting Detection:

International Perspectives on the Uses of a Plot (New York: Continuum, 2012), 184 pp., $£ 19.25$ (pbk)

One of the problems with books which are relatively general in nature is that many of the individual contributions tend to be so narrow and specialised that only the author has any knowledge of (or interest in) the issues under discussion. At first sight this appears to be the case with Detecting Detection. Fortunately, however, first impressions are deceiving. Although the essays in the volume deal with writers as diverse and disparate as the Catalano-Spanish writer Juan Marse, the Bulgarian-French philosopher Julia Kristeva and the once-vaunted giant of English literature, Graham Greene, among numerous others, there is much to be enjoyed and learnt, even if some of the works under discussion are unfamiliar to the crime fiction reader and/or scholar to whom the book initially appears to be directed.

The title, Detecting Detection, together with the blurb on the back of the book, strongly suggests that its contents will largely be about detective fiction or, to use a more catch-all term, crime fiction. It is true that the subtitle 'International perspectives on the uses of a plot' does not confirm this assumption, and a Swift meditation of the phrase 'detecting detection'should, perhaps, set off alarm bells with its suggestion that any detection in the book will have to be sought out in a sleuth-like fashion. But, the fact is, over half of the essays are not about detective fiction at all. This is disappointing because there are some magnificent crime 


\section{Textual Practice}

writers who deserve the kind of thorough-going breadth of analysis that this volume offers. Writers such as Don Winslow whose The Power of the Dog bears a number of similarities to Bolaño's The Savage Detectives, a novel analysed in Detecting Detection by Peter Baker, but which, despite its title, is not really a detective story, or even a crime novel except to the extent that many novels have their elements of crime and detection. Clearly the genre has been challenged, stretched, and broken, even from its very origins. To analyse a series of novels and authors in order to show how they are somehow related or relevant to 'detection' is problematic. Any book at random could be selected for that purpose, as seems to be the case with Michelle Robinson's study of John Kennedy Toole's 1980 surprise bestseller A Confederacy of Dunces , 'Two men walk into a bar'. Beginning with a comparison between jokes and detective stories, the essay concludes with the observation that Toole's posthumous recognition as a celebrated author is, if 'not an effect of detection [,] at least a good joke' (p. 78). On the other hand, I thought Rossita Terzieva-Artemis's study of Julia Kristeva's novel Possessions was justified given that it is in fact a crime novel, with bloody murder, mystery, and detection all playing their part and, it is true, the fact that it is by Kristeva gives it an undoubted aura.

That said, Kim Toft Hansen’s essay 'Knowing the unknowable: detecting metaphysics and religion in crime fiction' is by far the most comprehensive contribution, being neither confined to a single writer nor a single work, but providing an impressive overview of religion in crime fiction, from the Bible to twelfth century China, through to the rise of detective fiction as it is understood in the West during the nineteenth and twentieth centuries. I was particularly drawn to his argument that the fictional detective with his reliance 


\section{Book Reviews}

on reason, logic, and science, is not a substitute for religion, spirituality or the figure of the priest. I am not sure that I entirely agree with him, but his rebuttal of the widely held orthodoxy that 'crime fiction takes the place of religion' (p. 156) offers much food for thought.

The essay on African writing, 'African initiation narratives and the modern detective novel' by Amadou Kone, was certainly welcome, taking an unusual and challenging approach to the problematic of African crime writing. African detective fiction is currently undergoing a major boom, led by the Afrikaaner Deon Meyer, and followed closely by his South African compatriots Mike Nicol and Roger Smith. All three, however, are white and although increasing in numbers and sales, Black African crime writers have yet to achieve the same success. A notable exception is Meshack Masondo, whose crime fiction, written in isiZulu, remains largely unknown outside South Africa. Kone 's argument, then, that 'the detective novel has remained extremely rare in African novel production' (p. 169) is not entirely accurate; nevertheless, his decision to eschew the above-mentioned Euro-American style of crime novel altogether is justified both on ideological and literary grounds. Ideologically, because he prefers to analyse an alternative and genuinely African tradition of story-telling, rather than that of a colonial import; and, from a literary perspective, because he traces a number of interesting parallels between the figure of the fictional detective and the traditional African 'master initiator' (p. 178). These include his role as guide, interpreter of signs (or clues) and the custom of ensuring that the unveiling is delayed until the end of the narrative' (p. 179).

Sheng-mei Ma's contribution also observes crime fiction from the position of outsider and his study of the Chinese detective in Western fiction provides a timely reminder of the 


\section{Textual Practice}

stubborn endurance of Orientalism in Western culture. The Chinese detective, indeed almost any representation of the Asian, is all too frequently that of 'Zen master-cum-yellow slave suspended between the paradox of enlightenment and servitude' (p. 162). Women, too, are portrayed as contradictions, hovering 'between masculine aggression and feminine tenderness' (p. 127). Here Sheng-mei Ma is referring to Robert Hans van Gulik's Judge Dee series of crime novels, for which he has a particular dislike, but it is another author's depiction of a woman for whom he reserves his final attack: Stieg Larsson. Mentioned early on in the essay, and somewhat to the reader's bewilderment, Larsson's quirky heroine, Lisbeth Salander is subsequently described as 'a tease out of Larsson's subconsciousness, [her] alienness/Asianness derives from her Eastern/Russian descent, inducing stereotypical Asian expressionlessness and emotionlessness' (p. 131). The portrayal of both Asians (or non-whites) and women as inferior and inscrutable is commonplace in crime fiction, particularly of the hard-boiled kind associated with Raymond Chandler and Dashiell Hammett. Unfortunately, as Sheng-mei Ma shows, the tradition is alive and kicking. It is ironic that both Dashiell Hammett and Stieg Larsson (though not Raymond Chandler) were justifiably celebrated for their commitment to anti-racist and anti-fascist causes.

Ana-Marıa Medina's study of Juan Marse is also interesting, not because Marse is a crime writer, but because of Medina's argument that Spanish and Catalan detective fiction was fundamental to the development of his work. Indeed, most of the essay is devoted to the history of Spanish and Catalan crime fiction, and particularly to the importance of Barcelona. I was, however, rather surprised that there was no mention of Manuel Vázquez Montalban (1939 - 2003), 


\section{Book Reviews}

author of the celebrated Barcelona-based Pepe Carvalho novels, godfather of Mediterranean Noir and one of the greatest crime writers of all time. Perhaps she felt his work had no influence on, or relevance to, Marse 's. This brings me to Sofia Ahlberg's essay on Graham Greene. Why Graham Greene? There are, as I have said, so many fascinating crime writers of whom so much could be written: Vikram Chandra, James Sallis, Ken Bruen to name a very few men almost at random (no women writers are considered at any length in Detecting Detection, except for Kristeva). Ironically Ahlberg argues that 'For far too long, critics have been dismissive of the detective genre' (p. 88), so why does she choose to analyse the work of an author who is emphatically not defined or confined by genre? And if she chooses to insist on Greene's membership of the crime-writing fraternity, why does she cite only two works directly related to the genre? She also has some rather peculiar things to say. For example: 'While satisfying the reader's need for closure, the detective figure represents disorder' (p. 96), a state ment which flies in the face of conventional critical thought. Fair enough, if this can be justified, as Hansen does in his excellent essay on crime fiction and religion, but here it is not. The whole point of the detective, at least in crime fiction up until the 1970s, was that he, or she, was a figure representing order. He, or she, restores order. And if we want to analyse a text that selfconsciously deconstructs this convention, we need look no further than Dashiell Hammett's magnificent 1929 novel Red Harvest. Later on she says 'Detection manages to eschew the desire for self-knowledge in contemporary fiction' (p. 97). She has obviously not read the novels of Robert B. Parker and their lengthy, agonising explora tion of masculinity, or James Sallis's self-consciously postmodern Lew Griffin novels. Or the often angry interrogation of what it means to be a 
women in the detective novels of Sara Paretsky, Sue Grafton or Linda Barnes. Finally, the detective, she says, 'is always engaged in moral judgement' (p. 98). Yes, this is the traditional belief, as spelled out by Raymond Chandler in 'The Simple Art of Murder'. And Chandler's work is blighted with racism, misogyny, and homophobia. But detective fiction has moved on, as Paul Auster's self-consciously literary New York Trilogy demonstrates. Written in the guise of detective fiction, the Trilogy blatantly negates such concepts as morality, guilt, and innocence.

Bill Phillips

Universitat de Barcelona

2014 Bill Phillips

http://dx.doi.org/10.1080/0950236X.2014.943481 